УДК 347 (075.8)

\title{
H. В. Аніщук \\ УСПІШНІ ЖІНКИ-ЮРИСТИ У СВІТІ: КАР'ЄРА ВІД АДВОКАТА ДО ПРЕЗИДЕНТА ДЕРЖАВИ
}

Актуальність обраної теми полягає у тому, що на початку XXI ст. відбувається процес фемінізації адвокатури і пов'язано це із досягненням гендерної рівності у більшості країн світу. На сьогодні професія адвоката привертає увагу у представниць жіночої статі, зокрема, й в України. Слід зазначити, що в історії «жіночої адвокатури» відомі такі випадки, коли жінки-адвокати балотувалися на пост президента держави, і й інколи їм вдавалося перемогти на виборах та зайняти цю посаду. Щоправда, таких випадків у світі небагато, утім їх досвід, їх успіх у цьому напрямку заслуговує на увагу.

Аналіз останніх досліджень і публікацій, в яких започатковано розв'язання даної проблеми і на які спирається автор, дає підставу стверджувати, що на сьогодні у вітчизняній юридичній науці наразі бракує фундаментальних розробок, в яких із гендерних позицій розглядається адвокатура. Не применшуючи ролі та значущості розроблень правознавців (М. Аракеляна [1], Н. Бакаянової [2]), які досліджували окремі питання адвокатури, все ж таки необхідно визнати, що обрана проблема та висвітлення іiі в контексті гендерного аналізу недостатньо досліджена в юридичній науці. Усе вищенаведене зумовило вибір теми і мети дослідження, його наукову новизну і практичне значення.

Метою даної статті $є$ проведення гендерного дослідження у контексті висвітлення діяльності успішних жінок-юристів у світі, які побудували свою професійну кар'єру від адвоката до президента держави.

Виклад основного матеріалу. Починаючи із зародження адвокатури в стародавньому світі і до другої половини XIX ст., існувала чоловіча монополія на зайняття адвокатською професією. Протягом багатовікової історії в адвокатурі домінували чоловіки, і тому професія адвоката була чоловічою справою. Жінкам було заборонено займатися адвокатською діяльністю. Це було пов'язано із певними гендерними стереотипами, за якими жінки не сприймалися рівними із чоловіками, розглядалися як «слабка стать», а тому основним їх призначенням мало бути ведення домашнього господарства та виховування дітей. Отже професія юрист-адвокат була виключно справою для чоловіків. 
Стародавні Греція та Рим вважаються батьківщиною адвокатури. Відомо, що римський верховний жрець Тиберій Корунканій в III ст. до н.е. публічно надавав консультації громадянам по їх юридичним спорам. До цього моменту знання про право були скриті від рядових громадян, так що Тиберія Корункація можна вважати передумовою адвокатури.

Із появою адвокатури гендерний образ адвокатської професії спершу мав чоловічу спрямованість. Очевидною була маскулінізація адвокатури. Ще трохи більше століття тому слова «жінка» і «адвокат» означали взаємовиключні поняття. Ситуація почала змінюватися із фемінізацією суспільства, емансипацією жінок, коли вони почали активно завойовувати свої позиції у різних сферах життєдіяльності суспільства, зокрема, юридичній. Можна стверджувати, що образ «жінка-адвокат», як і власне термін «жіноча адвокатура» $є$ відносно новими. У світі почали з'являтися перші професійні жінки-адвокати лише наприкінці XIX - початку XX ст.: Арабелла Менсфілд (США, 1869), Клара Брет Мартін (Канада, 1897) та інші. Відтоді й починають у науковому світі вживати термін «жіноча адвокатура», під яким розуміється участь жінок-адвокатів у адвокатурі.

Яскравим прикладом можна привести наукову працю першої в історії вітчизняної адвокатури жінки-адвоката К.А. Флейшиц «О женской адвокатуре» (1910) [3]. Отже термін «жіноча адвокатура» $є$ відносно новим, його починають застосовувати відтоді, коли з'явилися у світі перші жінки-адвокати.

У західних країнах світу входження жінок у юридичний світ розпочалося наприкінці XIX ст. і продовжувалося до середини XX ст. Тогочасне суспільство із напруженістю ставилося до того, що жінки прагнули себе реалізувати в «чоловічому світі» юридичної професії. Аргументація проти прийому жінок в адвокатуру у багатьох країнах зводилася до наступного. Деякі стверджували, що заміжні жінки, приймаючи доручення від того чи іншого клієнта, будуть у сім'ї радитися із чоловіком, порушуючи цим конфіденційність. Ще одне поширене заперечення супротивників полягало у тому, що жінки не повинні бути адвокатами, тому що вони думають своїми серцями, а не головами. В суспільстві було поширене переконання, що жінки мають недостатній рівень логіки та самовладання; жінки -доволі емоційні істоти, і ці їх почуття завдадуть шкоди чистоті справедливості; жінки не мають жодного уявлення про такі поняття, як обгрунтованість, допустимість, аналогія, доказ та інші. Всі такі уявлення виходили із того, що «жінка - істота від природи емоційна, чутлива уразлива і в багатовіковій історії людства їй призначена роль дружини, матері, продовжувачки роду, берегині домашнього вогнища» [4].

Жінкам знадобилося докласти багато зусиль для того, щоб сьогодні, в XXI ст., нарівні з чоловіками займатися адвокатською діяльністю і примусити сучасне суспільство сприймати це як звичайне явище, яке не викликає негативної реакції. Нині у світі набуває поширення фемінізація адвокатури. Фемінізація - це зростання ролі та впливу жінок у суспільстві [5].

Виходячи з цього, поняття «фемінізація адвокатури» можна визначити, як збільшення частки жінок-адвокатів, зростання їх ролі та впливу у адвокатурі. Проте так було не завжди. Протягом багатовікової історії чоловіки 
не дозволяли жінкам займатися престижними і добре оплачуваними видами занять (зокрема, і юридичними справами), проте жінки не задовольнялися цим і поступово оволодівали тими професіями, які раніше належали чоловікам. Однак щойно жінкам стало дозволено приймати участь в адвокатурі (кінець XIX-XX ст.), ситуація змінилася. Чоловіки стали сприймати жінок як конкурентів і ставитися до них як до конкурентів. Водночас бажання жінок набути соціального статусу та вести більш яскраве, у порівнянні з їх матерями, життя, зі своєї сторони також сприяє збільшенню числа представниць «слабкої статі», які намагаються потрапити у професію адвоката.

В історії «жіночої адвокатури» відомі такі випадки, коли жінки-адвокати балотувалися на пост Президента країни, й іноді їм вдавалося перемогти на виборах та зайняти цю посаду. Щоправда таких випадків у світі небагато, утім їх досвід, їх успіх у цьому напрямку заслуговує на увагу.

Слід зазначити, що президент держави - глава держави і виконавчої влади або тільки держави. Інститут президентства бере свій початок 3 часів утворення США. Конституція цієї країни 1787 передбачила виборчу посаду президента США і закріпила його повноваження [6, с. 64]. Тепер ця посада є у більшості країн світу, в тому числі в Україні.

Традиційно у суспільстві вважається, що посада президента держави -це «чоловіча посада». Це відомий факт, враховуючи те, що в історії людства у переважній більшості країн на посту президента держави правили чоловіки. I лише у небагатьох країнах світу, жінкам вдалося перемогти на виборах та стати президентом держави.

На сьогодні жінки є президентами, зокрема, таких країн, як, Естонія, Литва, Мальта, Маршалові острови, Тайвань, Хорватія. Так, за освітою економіст Керсті Кальюлайд $є$ Президентом Естоніі; за освітою економіст Даля Грибаускайте - Президентом Литви; за освітою юрист Марі-Луіз Колейро Прека - Президентом Мальти; за освітою філолог, політолог Колінда Грабар-Кітарович - Президентом Хорватії; за освітою педагог Хільда Хейне - Президентом Маршалових островів; за освітою юрист Цай Інвень - Президентом Тайваню.

Слід зазначити, що першою жінкою-адвокатом у світі, яка зробила спробу висунути свою кандидатуру на пост Президента країни, стала американка Белва Локвуд (Belva Ann Lockwood 1830-1917). Вона стала першою жінкою в історії США (за іншими даними, другою - в деяких джерелах пальма першості надається Вікторії Вудхалл (Victoria Woodhull), що балотувалася на пост Президента США. Вперше Локвуд прийняла участь у виборах у 1884 р., вдруге - в 1888 р. [7]. Вона висувалася як кандидат від невеликої каліфорнійської партії, Національної партії рівності. Слід зазначити, що в 1986 р. у США було видано поштову марку із зображенням Белви Енн Локвуд - першої Американської жінки кандидата в Президенти США.

I хоча Белві Локвуд невдалося перемогти на виборах Президента США, утім можна з впевненістю стверджувати, що вона зробила великий внесок щодо фемінізації посади президента країни. Адже Белва Локвуд показала усьому світу приклад, що жінка, зокрема жінка-адвокат, прагне 
стати Президентом країни. В подальшому ії прикладом скористалися й інші жінки-адвокати у світі, зокрема, американка Хілларі Клінтон (Hillary Clinton 1947). Вищу юридичну освіту здобула в Йельському університеті, де згодом отримала ступінь доктора права. Довгий час працювала адвокатом. В 2009-2013 рр. займала посаду державного секретаря США [8]. У 2016 р. балотувалася на пост Президента США. На жаль, їй не вдалося отримати перемогу на виборах та стати першою жінкою в історії США на посту Президента країни. Утім для Америки результати іï виборів вказують на те, що вона успішно провела свою виборчу кампанію. Адже за рейтингами, Хілларі Клінтон посіла друге місце у виборах на пост Президента США. До неї жодна американська жінка не мала таких високих результатів на виборах Президента США.

Серед найвідоміших жінок-адвокатів Південної Америки заслуговує на увагу аргентинка Крістіна Елізабет Фернандес де Кіршнер (Cristina Elisabet Fernandes de Kirchner 1953). Їй вдалося просунутися на професійній сходинці від адвоката до Президента Аргентини. Вищу юридичну освіту вона отримала в Національному університеті Ла-Плати. Свою професійну кар'єру розпочала як адвокат. В 1976 р. після завершення навчання в університі працювала адвокатом у приватному адвокатському агентстві в Ріо-Гальєгос (провінція Санта-Крус). В 2007 р. Крістіну де Кіршнер було обрано Президентом Аргентини. Вона стала другою жінкою-президентом Аргентини (після Ісабель Перон). В 2011 р. її було переобрано на другий термін. Сьогодні вона входить до десятки найбільш впливових жінок-політичних лідерів світу [9].

Серед європейських країн, слід звернути увагу на Ірландію. У цій країні професія адвоката дозволила двом ірландським жінкам просунутися у своїй кар'єрі до посади Президента цієї країни. Так, Мері Робінсон (Mary Robinson 1944 року народження) стала першою жінкою в Ірландії, яку було обрано Президентом цієї країни (1990-1997), а з часом верховним комісаром ООН 3 прав людини (1997-2002). Свою професійну кар'єру розпочала як адвокат. В 1967 р. вона стала барристером Королівської корпорації барристерів м. Дубліна, а в 1968 р. - магістром права Гарвардського університета. В 1980 р. отримала посаду старшого адвоката. Протягом 20 років гідно засідала у Сенаті. Мері Робінсон називають ірландською Індірою Ганді [10].

Наступницею Мері Робінсон на посаді Президента Ірландії (1997-2011) стала Мері Макаліз (Mary McAleese 1951), яка також, як й попередня Президент, є адвокатом. Вона стала другою в історії Ірландії жінкою-президентом. Вищу юридичну освіту отримала у Королівському університеті у Белфасті. Розпочинала свою кар'єру як адвокат [11].

В історії Фінляндії також відомий випадок, коли жінка-юрист змогла просунутися у своїй професійній кар'єрі від юриста до Президента країни. Так, фінка Тар'я Халонен (Tarja Halonen 1943) отримала вищу юридичну освіту у Гельсінському університеті в 1968 р. Свою професійну кар'єру вона розпочала, як юрист в організації профспілок Фінляндії. Вона стала першою жінкою-президентом в історії Фінляндіi. Тар'я Халонен керувала 
країною протягом максимального терміну 12 років (2000-2012). Багато уваги приділяла питанням соціальної рівності та підкреслювала важливість турботи про обділених і слабких. Оскільки Конституція Фінляндії не дозволяє балотуватися тричі підряд, в 2012 р. Тар'я Халонен не змогла виставити свою кандидатуру на посаду Президента Фінляндії [12].

На даний час у світі є лише поодинокі випадки, коли жінки-юристи, посідають пост президента держави. Наприклад, у Мальті президентом країни є Марі-Луіз Колейро Прека (1958), юрист за освітою. За материнською лінією пов'язана із Домом Романових. Закінчила Університет Мальти, отримала ступінь бакалавра юридичних і гуманітарних наук. 1 квітня 2014 р. парламент обрав їі президентом. Вона стала дев'ятим, самим молодим президентом республіки і другою жінкою на цьому посту після Агати Барбари (1982-1987) [13].

У 2016 р. Цай Інвень (1956) стала першою жінкою-президентом Тайваню. Урочиста церемонія інавгурації першої жінки-президента пройшла в Тайбеї [14]. Зокрема, слід звернути увагу на іï біографічні дані у юридичній сфері. Так, у 1978 р. закінчила юридичний коледж Національного університету Тайваню. У 1980 р. отримала ступінь магістра в юридичній школі Корнельського університету. У 1984 р. в Лондонській школі економіки отримала ступінь доктора $(\mathrm{PhD})$ в галузі права. Після повернення 3 Лондона викладала право в університетах Тайбею.

Висновки. Таким чином, доходимо висновку, що професія адвоката надає можливість жінкам зробити блискучу професійну кар'єру не лише в юридичній діяльності, а й в інших сферах життєдіяльності суспільства. Нині у світі відомі приклади успішної роботи жінок-адвокатів, якім вдалося перемогти на виборах Президента країни та успішно реалізувати себе у цьому напрямку професійної кар'єри (Крістіна Елізабет Фернандес де Кіршнер (Аргентина), Мері Робінсон (Ірландія), Мері Макаліз (Ірландія), Тар'я Халонен (Фінляндія). На даний час жінки-юристи є президентами Мальти та Тайваню. Так, Марі-Луіз Колейро Прека є Президентом Мальти, а Цай Інвень $є$ Президентом Тайваню. Як уявляється, їх професійний досвід, знайомство із юриспруденцією допомагає успішно здійснювати керівництво країною. Це є стимулом для тих жінок-юристів, зокрема адвокатів, які в подальшому прагнуть приймати участь у виборах Президента країни та успішно реалізувати себе на цьому посту.

\section{Література}

1. Аракелян М.Р. Сравнительная адвокатура: курс лекций. Одесса: Юридична література, 2009. 236 c.

2. Бакаянова Н.М. Етичні принципи адвокатури в України: монографія. Одеса: Юридична література, 2005. 298 с.

3. Флейшиц Е.А. О женской адвокатуре / / Цивилист. Научно-практический журнал. М.: АНО «Юридические программы», 2008. № 2. С. 96-105.

4. Гармаш А., Королева С. Женщина в системе уголовного правосудия. URL: http:/ / justicemaker.ru/view-article.php?

5. ЯценкоН.Толковый словарьобществоведческих терминов.URL: http: / / www. slovarnik.ru / html-tsot / 6/6mansipasi8.html.

6. Юридична енциклопедія: В 6 т. / Редкол.: Ю. С. Шемшученко (голова редкол.) та ін. Т. 5: П-С; К.: Укр. енцикл., 2003. 736 с. 
7. Norgren Jill. Belva Lockwood. Blazing the Trail for Women in Law URL: http:/ / www. archives.gov/publacations/prologue/2005/spring/belva- lockwood.

8. Дедерихс М. Хиллари Клинтон и власть женщин. М.: ЦСЭН, 1995.

9. Вознесенская Э. Кристина Киршнер - биография Президента Аргентины. URL: http:/ / she-win.ru/politica/247 / cristina-kirchner.

10. Михеев В. Евросоюз дозрел до матриархата/ URL: http://alleuropalux.org/ ? $\mathrm{p}=2326 \&$ print $=$ print.

11. Marsh Michael. Mary McAleese. URL: http:/ / britanica.com/.../topic/...Mary-McAleese.

12. Печко В. Человек недели: Тарья Халонен. URL: www.euromag.ru/man_of.../18830.html.

13. URL: https: / / ib/ua/file/person/3778-mariluiz-koleyro-preka/html.

14. Перша жінка-президент Тайваню вступила на посаду. URL: https://www.bbc.com/ ukrainian/news-in-brief/2016/05/160520-om-taiwan-woman.

\section{А н о т а ц і я}

Аніщук Н. В. Успішні жінки-юристи у світі: кар'єра від адвоката до президента держави. - Стаття.

Стаття присвячена гендерному дослідженню юридичної професії, яка розкриває можливість реалізації в інших сферах, зокрема, політичній. Концентрується увага на висвітленні діяльності успішних жінок-адвокатів у світі, які успішно побудували свою кар'єру та стали Президентом країни.

Ключові слова: жінки-адвокати, президент, професія юрист, гендерна рівність, гендерні дослідження.

\section{Анн нот а ция}

Анищук Н. В. Успешные женщины-юристы в мире: карьера от адвоката до президента государства. - Статья.

Статья посвящена гендерному исследованию юридической профессии, которая раскрывает возможность реализации в других сферах, в частности, политической. Концентрируется внимание на освещении деятельности успешных женщин-адвокатов в мире, которые успешно построили свою карьеру и стали президентом страны.

Ключевые слова: женщины-адвокаты, президент, профессия юрист, гендерное равенство, гендерные исследования.

\section{S u m m a r y}

Anischuk N. V. Successful female lawyers in the world: career from advocate to president of the state. - Article.

The article is devoted to gender research of the legal profession, which reveals the possibility of realization in other spheres, in particular, political. The focus is on highlighting the activities of successful women lawyers in the world who successfully built their careers and became the president of the country.

Key words: women-lawyers, president, profession of a lawyer, gender equality, gender studies. 